\title{
RESEARCH
}

Open Access

\section{Laparoscopic resection of hepatic epithelioid hemangioendothelioma: report of eleven rare cases and literature review}

Jianjun $\mathrm{Xu}^{1+}$, Shaobo Hu${ }^{1,2+}$, Suzhen $\mathrm{Li}^{3}$, Weimin Wang ${ }^{1}$, Xing Zhou', Yuzhe $\mathrm{Wu}^{1}$, Zhe Su${ }^{1}$, Xiang Cheng ${ }^{1}$, Yang Gao ${ }^{1 *}$ and Qichang Zheng ${ }^{1 *}$

\begin{abstract}
Background: Hepatic epithelioid hemangioendothelioma (HEHE) is an extremely rare borderline tumor of vascular endothelial origin. Laparoscopic resection of HEHE has never been reported.

Methods: The clinical data of eleven patients with HEHE (4 women and 7 men) who were diagnosed and treated at the Union Hospital (Wuhan, China), and Wuhan Asia General Hospital (Wuhan, China), between March 2012 and July 2020 were analyzed retrospectively.

Results: The mean age of HEHE patients was $42.4 \pm 13.9$ years (range 22-67 years). All patients underwent laparoscopic surgery alone or in combination with radiofrequency ablation. Most tumors showed aggressive growth or metastasis. By immunohistochemistry, tumor cells were positive for CD31, CD34, ERG, PCK, FLi-1, TFE-3, and Ki-67 (labeling index range, 5-15\%). In one of the patients, the tumor was accompanied by partial necrosis with a local appearance of epithelioid angiosarcoma. Postoperative adjuvant treatment included chemotherapy, sorafenib, and Huaier granule. As of July 2020, the median follow-up duration was 36 months (range, 9-60 months), with 2 (18.2\%) patients experiencing tumor recurrence.
\end{abstract}

Conclusions: This is the first report of laparoscopic hepatectomy of HEHE. Curative laparoscopic hepatectomy might be an acceptable treatment for appropriate HEHE patients.

Keywords: Hepatic epithelioid hemangioendothelioma, Liver neoplasms, Laparoscopic hepatectomy, Targeted therapy

\footnotetext{
*Correspondence: hzkjdgy@163.com; zqcmd@126.com

Disclosure of significance: To the best of our knowledge, laparoscopic

resection of HEHE has never been described in the literature. This is the first

report of laparoscopic resection of hepatic epithelioid

hemangioendothelioma.

†Jianjun Xu and Shaobo Hu contributed equally to this work.

'Department of Hepatobiliary Surgery, Union Hospital, Tongji Medical

College, Huazhong University of Science and Technology, Wuhan 430022,

China

Full list of author information is available at the end of the article
}

(c) The Author(s). 2020 Open Access This article is licensed under a Creative Commons Attribution 4.0 International License, which permits use, sharing, adaptation, distribution and reproduction in any medium or format, as long as you give appropriate credit to the original author(s) and the source, provide a link to the Creative Commons licence, and indicate if changes were made. The images or other third party material in this article are included in the article's Creative Commons licence, unless indicated otherwise in a credit line to the material. If material is not included in the article's Creative Commons licence and your intended use is not permitted by statutory regulation or exceeds the permitted use, you will need to obtain permission directly from the copyright holder. To view a copy of this licence, visit http://creativecommons.org/licenses/by/4.0/ The Creative Commons Public Domain Dedication waiver (http://creativecommons.org/publicdomain/zero/1.0/) applies to the data made available in this article, unless otherwise stated in a credit line to the data. 


\section{Introduction}

Tumors of the liver are common, but the primary or secondary hepatic epithelioid hemangioendothelioma (HEHE) is rare [1]. In the majority of HEHE patients, multiple nodules are secondary and result from a systemic spreading of the disease. Epithelioid hemangioendothelioma occurs most frequently in the liver [2], lung [3], and bone [4]. HEHEs are extremely rare borderline tumor, while primary single nodule HEHE is even rarer due to its high metastatic potential. The definitive diagnosis of HEHE requires histopathological evaluation. At present, there is no consensus on the optimal treatment for HEHE, but surgical excision is often considered an effective treatment [5]. However, laparoscopic resection of HEHE is seldom reported in the literature. This report describes cases of curative laparoscopic resection of primary HEHE accompanied by vascular invasion.

\section{Patients and methods}

This retrospective study included eleven HEHE patients diagnosed on the basis of postoperative histopathology. These patients were treated between March 2012 and July 2020 at the Union Hospital, Tongji Medical College, Huazhong University of Science and Technology (Wuhan,
China), and Wuhan Asia General Hospital (Wuhan, China). The following data were extracted from the medical records of the patients: age, gender, results of physical examination, blood test results, treatment protocol, histopathology findings, and follow-up data.

The patients were evaluated at the hospital at 1 month after the operation, and then every 3 months for the next 2 years. Subsequently, they were examined every 6 months until the last follow-up (July 2020). Standard physical examination, blood test, and imaging were performed at every review. The final status of the patients was classified as tumor-free survival, tumor recurrence, or death. Tumor-free survival was calculated from the time of HEHE diagnosis to the time of recurrence.

This research was approved by the Ethical Review Committee of the Tongji Medical College, and informed consent was obtained from the study participants.

\section{Results}

Eleven patients, seven males and four females, diagnosed with HEHE were included in this retrospective study. Their basic clinical data are listed in Table 1. The mean age of patients was $42.4 \pm 13.9$ years (range $22-67$ years). Clinical symptoms included right upper abdominal pain,

Table 1 Clinical data of hepatic epithelioid hemangioendothelioma patients

\begin{tabular}{|c|c|c|c|c|c|c|c|c|}
\hline Patient & Age & Gender & $\begin{array}{l}\text { Follow-up } \\
\text { duration } \\
\text { (months) }\end{array}$ & $\begin{array}{l}\text { Number of } \\
\text { tumor }\end{array}$ & Metastasis & Pathology & Treatment & Recurrence \\
\hline 1 & 35 & Male & 60 & 1 & No & $\begin{array}{l}\text { CD31(+), CD34(+), ERG(+), } \\
\text { TFE-3(+), Ki67 (LI: } \\
\text { approximately 5\%) }\end{array}$ & $\mathrm{LH}$ & No \\
\hline 2 & 43 & Male & 48 & 2 & $\begin{array}{l}\text { Lymph } \\
\text { nodes }\end{array}$ & $\begin{array}{l}\text { CD31(+), CD34(+), ERG(+), } \\
\text { PCK(+), Ki67 (LI: approximately } \\
10 \%)\end{array}$ & LH + RFA + lymphadenectomy & Yes \\
\hline 3 & 67 & Female & 48 & 1 & No & $\begin{array}{l}\mathrm{CD} 31(+), \mathrm{CD} 34(+), \mathrm{ERG}(+), \\
\text { TFE-3(+), Ki67 (LI: } \\
\text { approximately 5\%) }\end{array}$ & $\mathrm{LH}$ & No \\
\hline 4 & 41 & Male & 42 & 1 & No & & $\mathrm{LH}+\mathrm{RFA}$ & No \\
\hline 5 & 28 & Female & 42 & 2 & $\begin{array}{l}\text { Lymph } \\
\text { nodes }\end{array}$ & $\begin{array}{l}\operatorname{CD} 31(+), \operatorname{CD} 34(+), \operatorname{ERG}(+) \\
\mathrm{FLi}-1(+), \mathrm{Ki} 67(\mathrm{LI}:<5 \%)\end{array}$ & LH + lymphadenectomy & Yes \\
\hline 6 & 22 & Male & 36 & 1 & No & $\begin{array}{l}\text { CD31(+), CD34(+), ERG(+), } \\
\text { Ki67 (LI: approximately 5\%) }\end{array}$ & LH + Huaier granule & No \\
\hline 7 & 53 & Male & 36 & 2 & No & $\begin{array}{l}\text { CD31(+), CD34(+), ERG(+), } \\
\text { PCK(+), Ki67 (LI: approximately } \\
5 \%)\end{array}$ & $\begin{array}{l}\mathrm{LH}+\text { sorafenib + Huaier } \\
\text { granule }\end{array}$ & No \\
\hline 8 & 39 & Female & 24 & 1 & No & $\begin{array}{l}\operatorname{CD} 31(+), \operatorname{CD} 34(+), \operatorname{ERG}(+) \\
\mathrm{FLi}-1(+), \mathrm{Ki} 67(\mathrm{LI}:<5 \%)\end{array}$ & $\mathrm{LH}$ & No \\
\hline 9 & 28 & Male & 12 & 3 & Gallbladder & $\begin{array}{l}\text { CD31(+), CD34(+), ERG(+), } \\
\text { PCK(+), Ki67 (LI: approximately } \\
5 \%)\end{array}$ & $\begin{array}{l}\text { LH + RFA + cholecystectomy } \\
+ \text { chemotherapy + sorafenib } \\
+ \text { Huaier granule }\end{array}$ & No \\
\hline 10 & 55 & Female & 12 & 2 & $\begin{array}{l}\text { Lymph } \\
\text { nodes }\end{array}$ & $\begin{array}{l}\text { CD31(+), CD34(+), ERG(+), } \\
\text { Ki67 (Ll: approximately 15\%) }\end{array}$ & $\begin{array}{l}\mathrm{LH}+\text { RFA + lymphadenectomy } \\
+ \text { sorafenib + Huaier granule }\end{array}$ & No \\
\hline 11 & 55 & Male & 9 & 1 & No & $\begin{array}{l}\mathrm{CD} 31(+), \mathrm{CD} 34(+), \mathrm{ERG}(+), \\
\text { TFE-3(+), Ki67 (LI: } \\
\text { approximately 5\%) }\end{array}$ & $\begin{array}{l}\mathrm{LH}+\text { sorafenib + Huaier } \\
\text { granule }\end{array}$ & No \\
\hline
\end{tabular}


abdominal distension, jaundice, and fever. Biochemical test documented an increase in alkaline phosphatase, $\gamma$ glutamyl transferase, and lactate dehydrogenase. The number of tumors varied from 1 to 3 , and all the lesions were located in the same hepatic lobe. Their diameter ranged from 1 to $9 \mathrm{~cm}$. All patients underwent CT and MRI scans. The enhanced CT and MRI imaging demonstrated the absence of intratumoral enhancement, but an evident enhancement of liver parenchyma at the edge of the lesion. Prior to operation, patient 9 and 10 received an ultrasoundguided liver biopsy of the liver lesion, which showed a large amount of hepatocellular necrosis mixed with some epithelial cells and failed to confirm the diagnosis of HEHE. All eleven patients underwent laparoscopic resection during which radiofrequency ablation (RFA) was performed on the surgical margin in some patients. The pathologic examination confirmed that all eleven patients underwent laparoscopic regular hepatic lobectomy with $\mathrm{R} 0$ resection. The surgical margin was more than $2 \mathrm{~cm}$ from the lesion. Postoperative adjuvant treatment included chemotherapy, sorafenib, and Huaier granule [6].

The histopathological findings documented that most of cross-section of the tumor were hoary. In some patients, tumor tissue exhibited necrosis and calcification. Especially in patient 10 , the HEHE was accompanied by partial necrosis with a local appearance of epithelioid angiosarcoma. Immunohistochemical staining indicated that tumor cells were positive for CD31, CD34, ERG, PCK, FLi-1, TFE-3, and Ki67 (labeling index, 5-15\%).

As of July 2020, the median duration of the follow-up was 36 months (range, 9-60 months), and all patients survived with 2 (18.2\%) patients experiencing local recurrence in the liver. None of the patients had postoperative distant metastasis. In addition, both patients with recurrence underwent CT-guided radiofrequency ablation of the percutaneous liver and achieved a radical curative effect.

\section{Presentation of a typical case}

A 55-year-old male patient had a progressively enlarging mass in the liver for one year. No abnormalities were found in routine blood tests. The coagulation function was normal. Biochemical tests demonstrated that the levels of indicators of liver and kidney function were also in the normal range. Additionally, tumor markers were not elevated. MRI imaging revealed that the subcapsular lesion of the SII segment of the liver was hypointense on T1-weighted images; the size of the lesion was approximately $2.6 \times 1.8 \mathrm{~cm}$, and its boundary was clearly defined (Fig. 1). The lesion was slightly hyperintense on T2-weighted images. Diffusionweighted imaging (DWI) demonstrated a mild limitation of dispersion. Enhanced MRI showed a slight ring-shaped enhancement after the administration of contrast agent. Additionally, enhanced MRI documented the presence of several typical cavernous hemangiomas in the liver; the largest of them was approximately $2.7 \times 2.2 \mathrm{~cm}$ and was located in the SII segment of the liver (red arrow). At the time of imaging, the liver mass was considered to be benign, and a follow-up was recommended. The second imaging of the liver mass was performed by computed tomography (CT) after 1 year of follow-up (Fig. 2). CT scans revealed a patchy low-density shadow (white arrow), approximately $4.5 \times 5.8 \mathrm{~cm}$ in size, under the capsule of the SII segment of the liver. The subcapsular lesion of the SII segment of the liver did not exhibit significant enhancement. Numerous typical cavernous hemangiomas (red arrows) with progressive enhancement on the enhanced CT scan were found in the liver; the largest of them, approximately $2.7 \times 2.2 \mathrm{~cm}$, was located in the SII segment

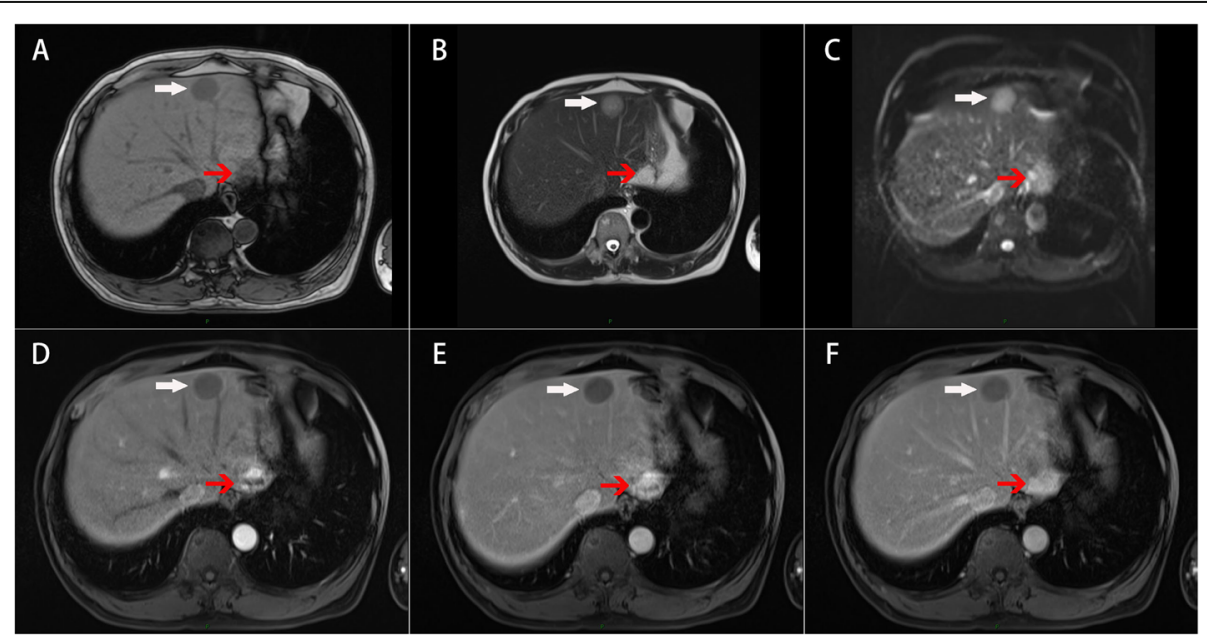

Fig. 1 Enhanced MRI scans. a Hypointense on T1-weighted images (white arrow). b Hyperintense on T2-weighted images. c DWI showed mild limitation of dispersion. $\mathbf{d}$ Ring-shaped enhancement. e Portal vein stage, slight ring-shaped enhancement. $\mathbf{f}$ Delayed stage, decreased enhancement. Cavernous hemangioma (red arrow) 

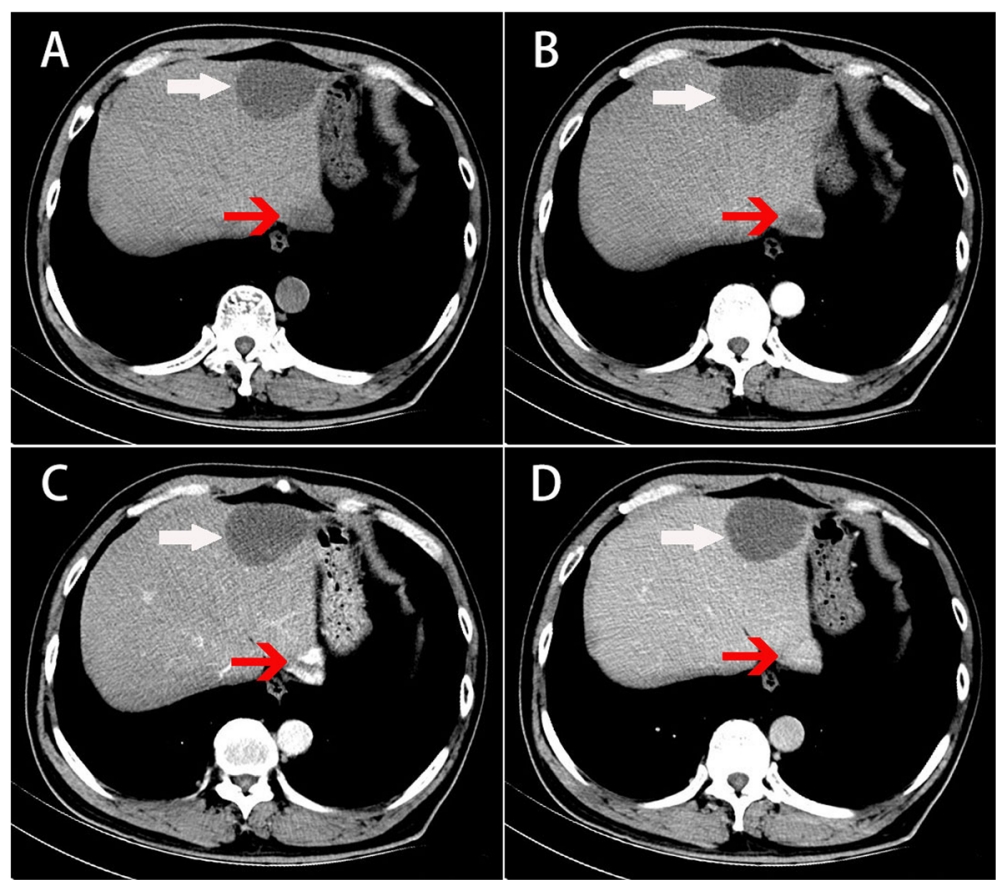

Fig. 2 Enhanced CT scans. a Plain scan, b arterial stage, c portal vein stage, $\mathbf{d}$ and delayed stage. A patchy low-density shadow without significant enhancement can be seen in the liver (white arrow). Cavernous hemangioma (red arrow)

of the liver. A number of small cysts were also detected in the liver, the larger of them reaching about $2-3 \mathrm{~mm}$ in diameter. Preoperatively, the patient differential diagnosis was "1. malignant tumor of the liver; 2. cavernous hemangioma of the liver; 3 . hepatic cyst". Taking into consideration the possibility of biopsy failure, bleeding, tumor metastasis, and the feasibility of complete resection of the liver mass, the decision was made to conduct laparoscopic hepatectomy of the left lateral hepatic lobe without performing a preoperative biopsy. After the procedure, the patient received sorafenib and Huaier granule as adjuvant therapy [6]. The patient was discharged 5 days after laparoscopic surgery. A follow-up at 9 months did not detect the recurrence of the tumor, and curative resection was asserted.

\section{Pathology}

The lesion was located under the capsule of the left lateral lobe of the liver (Fig. 3a). Its surface was slightly concave, a large number of new blood vessels were noted, and peritoneal adhesions were observed around the liver. The lesion was firm, and the sections were hoary (Fig. 3b). No tumor involvement was found at the surgical margin, indicating R0 resection. A definitive

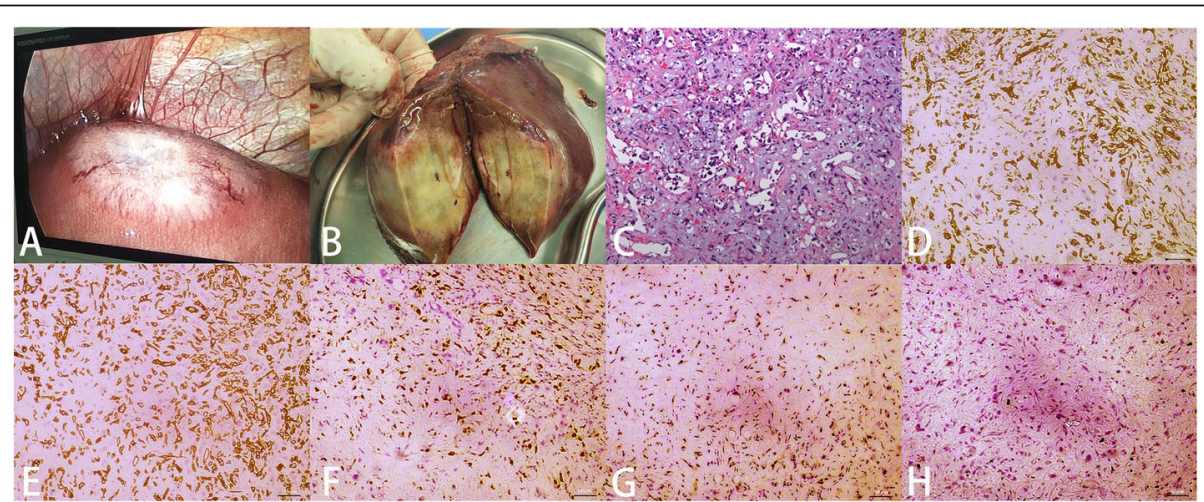

Fig. 3. Pathological examination. a Laparoscopic view, b postoperative gross solid horay specimens, and $\mathbf{c}$ histopathological section confirmed hepatic epithelioid hemangioendothelioma $(\mathrm{HE}, \times 200)$. Immunohistochemical staining documented the tumor was positive for CD31 (d), CD34 (e), ERG (f), and TFE-3 (g). Ki67 was approximately 5\% 
diagnosis of epithelioid hemangioendothelioma with microvascular invasion was confirmed by postoperative pathological examination (Fig. 3c). By immunohistochemistry, the tumor was positive for CD31, CD34, ERG, and TFE-3 and negative for PCK, CK8/18, EMA, CK19, Glypican3, hepatocytes, and arginase. Approximately $5 \%$ of tumor cells were Ki67-positive.

\section{Literature review}

Any searchable literature in the PubMed, Google Scholar, and Web of Science databases concerning surgical treatment of primary HEHE, whatever language it was published in, is included. The search term used was (((((Epithelioid Hemangioendothelioma) OR (Epithelioid Hemangioendotheliomas)) OR (Hemangioendotheliomas, Epithelioid) AND ((liver) OR (hepatic) AND)) AND (((surgery) OR (operati*)) OR (therapy)) AND (surviv*). A total of 44 papers were retrieved. Finally, twenty papers on surgical treatment of HEHE and providing survival information were listed in Table 2. The references mentioned in Table 2 are included in the supplementary document.

\section{Discussion}

HEHE is an extremely rare borderline tumor of mesenchymal tissue-vascular endothelium origin and affects less than one in a million individuals [7]. The degree of malignancy of epithelioid hemangioendothelioma varies greatly between benign disease and aggressive cancer with widespread metastases. A case of meningeal epithelioid hemangioendothelioma with WWTR1-CAMTA1 gene fusion, growing slowly for more than 15 years, has been reported [8]. There have also been cases of patients with diffuse HEHE producing multiple splenic metastases and delayed multifocal bone metastases [9]. Primary HEHE refers to the invasion of the liver by a tumor originating in the liver mesenchyma rather than in other organs. HEHE consisting of a single lesion is considered to be the early stage of epithelioid hemangioendothelioma [3]. HEHE develops more frequently in males than in females, and appears to be associated with infections by hepatitis B- or C-viruses [10]. However, the exact pathogenesis of HEHE remains unclear.

The clinical presentation of most HEHE patients is nonspecific, with the pain in the right upper abdomen being the most common symptom. With the growth of volume and number of the masses, the occupied space increases, producing tension in the liver capsules and leading to pain. Additionally, the gradual enlargement of HEHE generates the risk of spontaneous rupture and hemorrhage [11]. HEHE has also been reported to cause secondary BuddChiari syndrome [12]. Other symptoms of HEHE include ascites, weight loss, jaundice, and liver enlargement. The most commonly reported biochemical abnormality associated with HEHE is the elevation of alkaline phosphatase, but the level of other liver enzymes, including $\gamma$-glutamyl transferase, lactate dehydrogenase, aspartate aminotransferase, and alanine aminotransferase, may also be increased.

All HEHE lesions showed low density on CT plain scan, and round areas of even lower density were detected within some lesions [13]. On MRI scans, HEHE lesions were characterized by nodules with low signal intensity on T1-weighted images and high signal intensity on T2weighted images, compared to normal liver parenchyma. Other reported imaging features of HEHE include the "lollipop sign" and capsule retraction [13]. On contrastenhanced CT and MRI, a variety of enhancements in the lesion were seen, including annular, delayed, and uneven enhancement; absence of enhancement was also present. Previous studies have documented that contrast-enhanced ultrasound of HEHE was characterized by an excessive rim or heterogeneous enhancement in the arterial phase, and marginal enhancement in the portal and late phases [14]. 18F-FDG PET/CT showed diffuse HEHE with mild to moderate hypermetabolism, multiple coalescent subcapsular hypodense lesions in the liver, and relative hypometabolism in the central area [15].

At present, the diagnosis of HEHE depends on the results of pathologic and immunohistochemical evaluation and is difficult to be obtained by an ultrasound-guided liver biopsy [16]. By immunohistochemistry, HEHE cells are positive for CD31, CD34, ERG, PCK, FLi-1, and TFE-3. Factor VIII-related antigen is expressed in almost $100 \%$ of HEHE, but the degree of its staining may be highly variable among the cells in the lesion [10]. The presence of CAMTA1-WWTR1 fusion products in HEHE helps to differentiate between hemangioma and angiosarcoma [17]. Typically, there is no clear association between the histology of liver lesions and the clinical course of the disease [10].

There is no standard treatment strategy for HEHE. A comprehensive literature review showed that the 1-year, 3 -year, and 5-year overall survival rate of all 253 diagnosed individuals were 211 (83.4\%), 141 (55.7\%), and 104 (41.1\%), respectively [18]. The most commonly used treatment for HEHE was hepatectomy, liver transplantation, radiotherapy and/or chemotherapy, and observational follow-up. Hepatectomy yielded the highest, up to $75 \%$, 5year survival rate [19]. Partial hepatectomy may not be a viable option for many patients due to high metastatic potential of HEHE, resulting in multiple tumor lesions. The reported chemotherapeutic agents include interferonalpha, thalidomide, 5-fluorouracil, and monoclonal antibodies against vascular endothelial growth factor $[19,20]$. Molecularly targeted drugs include sorafenib and apadinil [21]. Huaier granule is a water-based product of Huaier extract, which is approved traditional Chinese medicine by Chinese State Food and Drug Administration and can be used alone or in combination with other drugs to treat 
Table 2 Summary of operative treatment of outcomes of hepatic epithelioid hemangioendothelioma with survival data in reviewed literatures

\begin{tabular}{|c|c|c|c|c|c|c|c|}
\hline Author (year) & No. & Diagnostic methods & $\begin{array}{l}\text { Tumor size, } \\
\text { mean, } \mathrm{cm}\end{array}$ & Metastasis & Operative approach & $\begin{array}{l}\text { Recurrence } \\
\text { rate, } \%\end{array}$ & Survival, \% \\
\hline $\begin{array}{l}\text { Konstantinidis } \\
\text { et al. (2018) [1] }\end{array}$ & 67 & & 14.8 & NA & $\mathrm{LR}$ or $\mathrm{LT}$ & NA & 83.4 (5-year) \\
\hline $\begin{array}{l}\text { Lai et al. } \\
\text { (2017) [2] }\end{array}$ & 149 & $\begin{array}{l}\text { Percutaneous and/or } \\
\text { surgical biopsy }\end{array}$ & NA & Lung, breast & LT and adjuvant therapy & $24.8 \%$ & 81 (5-year) \\
\hline $\begin{array}{l}\text { Dong et al. } \\
\text { (2015) [3] }\end{array}$ & 3 & Liver biopsy & NA & NA & $\mathrm{LR}$ and RFA, or LT & 0 & 100 (3-year) \\
\hline $\begin{array}{l}\text { Remiszewski } \\
\text { et al. (2014) [4] }\end{array}$ & 10 & $\begin{array}{l}\text { Liver biopsy during } \\
\text { diagnostic } \\
\text { laparoscopy }\end{array}$ & 5.1 & $\begin{array}{l}\text { Lymph node } \\
\text { metastases }\end{array}$ & LT & 0 & 90 (5-year) \\
\hline $\begin{array}{l}\text { Noh et al. } \\
\text { (2020) [5] }\end{array}$ & 19 & Liver biopsy & 3.53 & NA & $\begin{array}{l}\text { LR, } L R+\text { chemotherapy, } \\
L T \text { + radiation therapy, } \\
L T \text { + chemotherapy }\end{array}$ & NA & 88 (5-year) \\
\hline $\begin{array}{l}\text { Wang et al. } \\
\text { (2018) [6] }\end{array}$ & 1 & Liver biopsy & 4.7 & No & LR + chemotherapy & 0 & 100 (15-year) \\
\hline $\begin{array}{l}\text { Sanduzzi- } \\
\text { Zamparelli et al. } \\
\text { (2020) [7] }\end{array}$ & 11 & $\begin{array}{l}\text { Surgical specimens, } \\
\text { needle biopsy or } \\
\text { "wedge-biopsy" }\end{array}$ & & $\begin{array}{l}\text { Lung, Lymph } \\
\text { node metastases }\end{array}$ & LR or LT & 36.4 & 100 (5-year) \\
\hline $\begin{array}{l}\text { Orlando et al. } \\
(2013) \text { [8] }\end{array}$ & 108 & $\begin{array}{l}\text { Percutaneous needle, } \\
\text { surgical, or } \\
\text { combined biopsies }\end{array}$ & NA & $\begin{array}{l}\text { Osseous and } \\
\text { peritoneal } \\
\text { localizations }\end{array}$ & LT & NA & 72 (5-year) \\
\hline $\begin{array}{l}\text { Jung et al. } \\
\text { (2016) [9] }\end{array}$ & 6 & Liver biopsy & NA & NA & HR or LT & 16.7 & 83.3 (5-year) \\
\hline $\begin{array}{l}\text { Abdoh et al. } \\
\text { (2016) [10] }\end{array}$ & 1 & Liver biopsy & NA & $\begin{array}{l}\text { Intrahepatic } \\
\text { metastasis }\end{array}$ & LT & 100 & 0 (1-year) \\
\hline $\begin{array}{l}\text { Theodosopoulos } \\
\text { et al. (2013) [11] }\end{array}$ & 5 & Liver biopsy & 4 & $\begin{array}{l}\text { Intrahepatic } \\
\text { metastasis }\end{array}$ & $\begin{array}{l}\text { Surgical resection with a } \\
\text { non-formal hepatectomy } \\
\text { or wedge resection. }\end{array}$ & 40 & 60 (2-year) \\
\hline $\begin{array}{l}\text { Grotz et al. } \\
\text { (2010) [12] }\end{array}$ & 22 & Liver biopsy & NA & $\begin{array}{l}\text { Lung, peritoneum, } \\
\text { bone, brain and } \\
\text { skin }\end{array}$ & $\mathrm{LR}$ or $\mathrm{LT}$ & 40 & $\begin{array}{l}62 \text { (LR, 5-year), } 46 \\
(L T, 5 \text {-year) }\end{array}$ \\
\hline $\begin{array}{l}\text { Wang et al. } \\
\text { (2012) [13] }\end{array}$ & 21 & Surgical specimens & NA & $\begin{array}{l}\text { Lung metastases, } \\
\text { diaphragm/ } \\
\text { abdominal-wall } \\
\text { metastases }\end{array}$ & $\begin{array}{l}\mathrm{LR}, \mathrm{LR} \text { followed by TACE, } \\
\text { or } L T\end{array}$ & NA & $\begin{array}{l}74.1 \text { (LR, 3-year), } 33.3 \\
\text { (LR followed by TACE, } \\
\text { 3-year), } 0 \text { (LT, 3-year), }\end{array}$ \\
\hline $\begin{array}{l}\text { Thomas et al. } \\
\text { (2012) [14] }\end{array}$ & 7 & $\begin{array}{l}\text { Liver biopsy, diagnostic } \\
\text { laparoscopy, surgical } \\
\text { specimens }\end{array}$ & 3.6 & Lung & Hepatectomy or LT & 43 & 83 (5-year) \\
\hline $\begin{array}{l}\text { Krasnodębski } \\
\text { et al. (2020) [15] }\end{array}$ & 18 & Liver biopsy & NA & Hilar lymph nodes & LT & 0 & 41.3 (5-year) \\
\hline $\begin{array}{l}\text { Thin et al. } \\
\text { (2010) [16] }\end{array}$ & 1 & Liver biopsy & NA & $\begin{array}{l}\text { Intrahepatic } \\
\text { metastasis }\end{array}$ & LT & 0 & 100 (5-year) \\
\hline $\begin{array}{l}\text { Lin et al. } \\
\text { (2015) [17] }\end{array}$ & 1 & Surgical specimens & NA & No & LT & 0 & 100 (5-year) \\
\hline $\begin{array}{l}\text { Samuk et al. } \\
\text { (2016) [18] }\end{array}$ & 1 & Liver biopsy & NA & Lung & LT & 0 & 100 (5-year) \\
\hline $\begin{array}{l}\text { Sundar et al. } \\
\text { (2015) [19] }\end{array}$ & 11 & Liver biopsy & NA & NA & LT & NA & 78.7 (5-year) \\
\hline $\begin{array}{l}\text { Groeschl et al. } \\
\text { (2014) [20] }\end{array}$ & 12 & $\begin{array}{l}\text { Liver biopsy, surgical } \\
\text { specimens }\end{array}$ & NA & NA & $\begin{array}{l}\text { Segmental resection, } \\
\text { lobectomy/extended } \\
\text { resection, LT }\end{array}$ & NA & $\begin{array}{l}57(\mathrm{LR}, 1 \text {-year), } 80 \text { (LT, } \\
\text { 1-year), }\end{array}$ \\
\hline
\end{tabular}


a variety of malignant tumors, including liver cancer [6]. Huaier granule exerts an anti-tumor response by inhibiting tumor angiogenesis and inducing cell cycle arrest at the G0/G1 checkpoint [22]. In addition, it regulates innate immunity by stimulating cytokine release and production of $\mathrm{NO}$ and reactive oxygen species [6]. A previous randomized, parallel controlled, nationwide multicenter study confirmed that the Huaier granule could reduce the recurrence of liver cancer after radical resection [6], and the risk of HEHE postoperative recurrence. However, the research on adjuvant therapy after the radical resection of HEHE only begins to develop.

Further studies designed as large multi-center trials would be needed to provide definitive guidelines for the diagnosis and treatment of HEHE. However, because HEHE is rare, the implementation of this type of studies presents a challenge. These circumstances highlight the value of reporting rare cases of HEHE. Although laparoscopic-guided liver biopsy has been used to verify HEHE diagnosis of HEHE [16], there are no previous reports of laparoscopic resection of HEHE. To the best of our knowledge, this is the first report of laparoscopic resection of hepatic epithelioid hemangioendothelioma.

\section{Conclusions}

Primary HEHE is an extremely rare liver borderline tumor of vascular endothelial origin. This is the first report of laparoscopic hepatectomy of hepatic epithelioid hemangioendothelioma. Curative laparoscopic hepatectomy might be an acceptable treatment for appropriate HEHE patients.

\section{Supplementary information}

Supplementary information accompanies this paper at https://doi.org/10 1186/s12957-020-02034-Z.

Additional file 1:. References mentioned in Table 2

\section{Acknowledgements}

This work was supported by the National Natural Science Foundation of China (No. 81874231, No. 81903173) and the Natural Science Foundation of Hubei Province (No. 2019CFB729).

\section{Authors' contributions}

Jianjun Xu, Shaobo Hu, Yang Gao, and Qichang Zheng researched literature and conceived the study. Suzhen Li, Weimin Wang, Xing Zhou, Yuzhe Wu, Zhe Su, and Xiang Cheng were involved in protocol development, gaining ethical approval, patient recruitment, and data analysis. Jianjun Xu and Shaobo Hu wrote the first draft of the manuscript. All authors reviewed and edited the manuscript and approved the final version of the manuscript.

\section{Funding}

This work was supported by the National Natural Science Foundation of China (No. 81874231, No. 81903173) and the Natural Science Foundation of Hubei Province (No. 2019CFB729).

\section{Availability of data and materials}

The datasets used and/or analyzed during the current study are available from the corresponding author on reasonable request.
Ethics approval and consent to participate

This retrospective study was approved by the Tongji Medical College research ethics committee, Wuhan, China.

\section{Consent for publication}

We have obtained informed consent from patient.

\section{Competing interests}

All authors indicate no potential conflicts of interest.

\section{Author details}

'Department of Hepatobiliary Surgery, Union Hospital, Tongji Medical College, Huazhong University of Science and Technology, Wuhan 430022, China. ${ }^{2}$ Department of General Surgery, The People's Hospital of Honghu

City, Honghu 433200, China. ${ }^{3}$ Department of Gastroenterology, Wuhan Asia General Hospital, Wuhan 430056, China.

Received: 10 July 2020 Accepted: 22 September 2020

Published online: 29 October 2020

\section{References}

1. Hu HJ, Jin YW, Jing QY, Shrestha A, Cheng NS, Li FY. Hepatic epithelioid hemangioendothelioma: dilemma and challenges in the preoperative diagnosis. World J Gastroenterol. 2016;22(41):9247-50.

2. Agostini-Vulaj D, Pehlivanoglu B, Weiss SW, Krasinskas A, Feely MM, Hornick $J$, et al. Intrasinusoidal spread of hepatic epithelioid hemangioendothelioma: implications for the diagnosis in minimal samples. Am J Surg Pathol. 2019;43(4):573-9.

3. Afrit M, Nasri M, Labidi S, Mejri N, El Benna H, Boussen H. Aggressive primary hepatic epithelioid hemangioendothelioma: a case report and literature review. Cancer Biol Med. 2017;14(2):187-90.

4. Zeng $Y$, Leng $X$, Chen $P$, Luo J, Zhou Z. Imaging diagnosis of epithelioid hemangioendothelioma in thoracic vertebrae and liver. Ann Thorac Surg. 2020;109(6):e407-10

5. Cao L, Hong J, Zhou L, Ye Y, Liu Y, Yu J, et al. Selection of treatment for hepatic epithelioid hemangioendothelioma: a single-center experience. World J Surg Oncol. 2019;17(1):183.

6. Chen Q, Shu C, Laurence AD, Chen Y, Peng BG, Zhen ZJ, et al. Effect of Huaier granule on recurrence after curative resection of HCC: a multicentre, randomised clinical trial. Gut. 2018;67(11):2006-16.

7. Arai J, Shimozuma Y, Otoyama Y, Sugiura I, Nakajima Y, Hayashi E, et al. Three cases of histologically proven hepatic epithelioid hemangioendothelioma evaluated using a second-generation microbubble contrast medium in ultrasonography: case reports. BMC Gastroenterol. 2019;19(1):187.

8. Suss P, Volz F, Lang C, Staszewksi O, Palmedo G, Taschner CA, et al. A case of large meningeal epithelioid hemangioendothelioma with WWTR1-CAMT A1 gene rearrangement and slow growth over 15 years. J Neuropathol Exp Neurol. 2018;77(10):871-6.

9. Tan Y, Yang X, Dong C, Xiao Z, Zhang H, Wang Y. Diffuse hepatic epithelioid hemangioendothelioma with multiple splenic metastasis and delayed multifocal bone metastasis after liver transplantation on FDG PET/ CT images: a case report. Medicine. 2018;97(22):e10728.

10. Makhlouf HR, Ishak KG, Goodman ZD. Epithelioid hemangioendothelioma of the liver: a clinicopathologic study of 137 cases. Cancer. 1999;85(3):562-82.

11. Yang JW, Li Y, Xie K, Dong W, Cao XT, Xiao WD. Spontaneous rupture of hepatic epithelioid hemangioendothelioma: a case report. World J Gastroenterol. 2017;23(1):185-90.

12. Hayashi $Y$, Inagaki $K$, Hirota S, Yoshikawa T, Ikawa H. Epithelioid hemangioendothelioma with marked liver deformity and secondary Budd-Chiari syndrome: pathological and radiological correlation. Pathol Int. 1999;49(6):547-52.

13. Zhou L, Cui MY, Xiong J, Dong Z, Luo Y, Xiao H, et al. Spectrum of appearances on CT and MRI of hepatic epithelioid hemangioendothelioma. BMC Gastroenterol. 2015;15:69.

14. Dong Y, Wang WP, Cantisani V, D'Onofrio M, Ignee A, Mulazzani L, et al. Contrast-enhanced ultrasound of histologically proven hepatic epithelioid hemangioendothelioma. World J Gastroenterol. 2016;22(19):4741-9.

15. Ozguven S, Kesim S, Oksuzoglu K, Dane F, Ones T, Erdil TY. (18)F-FDG PET/ $\mathrm{CT}$ findings of a rare case of diffuse hepatic epithelioid hemangioendothelioma with bone metastases at diagnosis. Rev Esp Med Nucl Imagen Mol. 2020;39(1):39-40. 
16. Deng Y, Zhou Y, Cheng N. Laparoscopic liver biopsy in the diagnosis of hepatic epithelioid hemangioendothelioma: a case report. Oncol Lett. 2014;8(3):1317-9.

17. Errani C, Sung YS, Zhang L, Healey JH, Antonescu CR. Monoclonality of multifocal epithelioid hemangioendothelioma of the liver by analysis of WWTR1-CAMTA1 breakpoints. Cancer Gene Ther. 2012;205(1-2):12-7.

18. Mehrabi A, Kashfi A, Fonouni H, Schemmer P, Schmied BM, Hallscheidt P, et al. Primary malignant hepatic epithelioid hemangioendothelioma: a comprehensive review of the literature with emphasis on the surgical therapy. Cancer. 2006;107(9):2108-21.

19. Lin $Y-H$, Lin C-C, Concejero AM, Yong C-C, Kuo F-Y, Wang C-C. Surgical experience of adult primary hepatic sarcomas. World J Surg Oncol. 2015;13:87.

20. Lau A, Malangone S, Green M, Badari A, Clarke K, Elquza E. Combination capecitabine and bevacizumab in the treatment of metastatic hepatic epithelioid hemangioendothelioma. Ther Adv Med Oncol. 2015;7(4):229-36.

21. Chevreau C, Le Cesne A, Ray-Coquard I, Italiano A, Cioffi A, Isambert N, et al. Sorafenib in patients with progressive epithelioid hemangioendothelioma: a phase 2 study by the French Sarcoma Group (GSF/GETO). Cancer. 2013: 119(14):2639-44

22. Wang $X$, Zhang N, Huo Q, Yang Q. Anti-angiogenic and antitumor activities of Huaier aqueous extract. Oncol Rep. 2012;28(4):1167-75.

\section{Publisher's Note}

Springer Nature remains neutral with regard to jurisdictional claims in published maps and institutional affiliations.

Ready to submit your research? Choose BMC and benefit from:

- fast, convenient online submission

- thorough peer review by experienced researchers in your field

- rapid publication on acceptance

- support for research data, including large and complex data types

- gold Open Access which fosters wider collaboration and increased citations

- maximum visibility for your research: over $100 \mathrm{M}$ website views per year

At $\mathrm{BMC}$, research is always in progress.

Learn more biomedcentral.com/submissions 